Article

\title{
The Effect of Primary, Secondary, and Tertiary Wastewater Treatment Processes on Antibiotic Resistance Gene (ARG) Concentrations in Solid and Dissolved Wastewater Fractions
}

\author{
Jennipher Quach-Cu ${ }^{1}$, Bellanira Herrera-Lynch ${ }^{1}$, Christine Marciniak ${ }^{1,2}{ }^{2}$ Scott Adams ${ }^{1}$, \\ April Simmerman ${ }^{1}$ and Ryan A. Reinke ${ }^{1, *}$ \\ 1 Water Quality Laboratory, Los Angeles County Sanitation Districts, Whittier, CA 90601, USA; \\ jquach-cu@lacsd.org (J.Q.-C.); BLynch@lacsd.org (B.H.-L.); webchristine@gmail.com (C.M.); \\ sadams@lacsd.org (S.A.); asimmerman@lacsd.org (A.S.) \\ 2 Vantari Genetics, Irvine, CA 92618, USA \\ * Correspondence: rreinke@lacsd.org; Tel.: +1-562-908-4288 (ext. 3059)
}

Received: 20 November 2017; Accepted: 27 December 2017; Published: 4 January 2018

\begin{abstract}
Wastewater treatment plants (WWTPs) have been identified as potential sources of antibiotic resistance genes (ARGs) but the effects of tertiary wastewater treatment processes on ARGs have not been well characterized. Therefore, the objective of this study was to determine the fate of ARGs throughout a tertiary-stage WWTP. Two ARGs, sul1 and bla, were quantified via quantitative polymerase chain reaction (qPCR) in solids and dissolved fractions of raw sewage, activated sludge, secondary effluent and tertiary effluent from a full-scale WWTP. Tertiary media filtration and chlorine disinfection were studied further with the use of a pilot-scale media filter. Results showed that both genes were reduced at each successive stage of treatment in the dissolved fraction. The solids-associated ARGs increased during activated sludge stage and were reduced in each subsequent stage. Overall reductions were approximately four $\log _{10}$ with the tertiary media filtration and disinfection providing the largest decrease. The majority of ARGs were solids-associated except for in the tertiary effluent. There was no evidence for positive selection of ARGs during treatment. The removal of ARGs by chlorine was improved by filtration compared to unfiltered, chlorinated secondary effluent. This study demonstrates that tertiary-stage WWTPs with disinfection can provide superior removal of ARGs compared to secondary treatment alone.
\end{abstract}

Keywords: antibiotic resistance genes; wastewater treatment; tertiary media filtration

\section{Introduction}

Antibiotic resistant bacteria (ARB) are having profound effects on the treatment of human diseases. In the United States, the number of ARB-related hospitalizations continues to increase [1] with an estimated cost of up to $\$ 30$ billion annually [2]. In recent years the importance of ARB has come to the forefront of many scientific disciplines including environmental microbiology. Antibiotic resistant genes in the environment have the potential to spread into the human population presenting a possible public health problem. Although the full impact of environmental transfer of antibiotic resistance genes (ARGs) on public health is not currently known, several reports have highlighted the presence of ARB and ARGs in wastewater treatment plants [3-8], agricultural feedlots [9-11] soils [12], rivers and lakes [9,13-18] raising concerns about potential public health impacts from these sources. As the number and cost of ARB-related illnesses continues to grow, multifaceted efforts are needed to control ARB in the clinic along with further investigation into potential impacts arising from environmental sources. 
The presence of antibiotics and ARB in wastewater treatment plants (WWTPs) and water reclamation plant (WRP) effluents are of specific interest. The primary reasons for concern include the presence of clinically relevant ARB and ARGs in raw sewage entering these facilities, the potential for ineffective removal and/or selection of ARG/ARB by WWTPs and, the possibility of human contact with treated waters $[13,17,19]$. Additionally, some studies have revealed the presence of ARB in treated wastewater effluents and have shown that ARGs and ARB are more prevalent downstream from WWTPs $[3,15,20-25]$ which suggest WWTPs have the potential to influence the ARB population in receiving waters. Almost all of these reports, however, focused on the impact of facilities using traditional primary and secondary stage treatments with or without disinfection. Currently, the effects of tertiary wastewater treatment processes, such as media filtration, on ARB and ARGs have not been well characterized.

Conventional activated sludge wastewater treatment is divided into distinct stages. The first or primary stage consists of physical removal of oils and greases along with sedimentation of large particles. The secondary phase of treatment utilizes microbial organisms to reduce the amount of organic matter in the wastewater. Typically, processes in addition to traditional secondary treatment which are employed to further improve water quality are referred to as tertiary-stage treatment [26]. Filtration, a commonly used type of tertiary treatment, has been shown to be effective in reducing the concentrations of viable indicator bacteria and viruses such as bacteriophage, substantially decreasing the number of hazardous microbes in final effluent waters [27]. Furthermore, tertiary filtration yields additional reductions in suspended solids and biological oxygen demand producing a higher quality effluent. Consequently, disinfection of tertiary effluents can be more efficient due to lower chlorine demand and higher transmittance of UV light compared to secondary effluent [28].

The public health and environmental hazards associated with ARGs are related to their capacity to be transferred between bacteria coupled with positive selective pressure occurring from the pervasive use of antibiotics both clinically and agriculturally. Specifically, the transfer of ARGs between bacteria horizontally is one of the main factors that have led to the rapid spread of antibiotic resistance across the globe $[29,30]$. The three main mechanisms by which ARGs are acquired by bacteria include: the direct exchange of genetic material between two viable bacteria (conjugation), through phage infections (transduction) and by uptake of extracellular, free DNA (transformation). Data has been presented indicating that horizontal gene transfer (HGT) of resistant genes occurs at a higher frequency among more closely related bacteria [31].

When considering the potential environmental impact of ARGs related to anthropogenic activities, it is important to recognize that ARGs occur naturally and can readily be found in environmental matrices unaffected by human activities [32-35]. Antibiotic resistance genes and ARB have been found in 30,000 year old permafrost as well as in remote caves isolated from humans for over four million years $[36,37]$ signifying that these genes are commonly found in the environment and have evolved over thousands to millions of years prior to the therapeutic use of antibiotics by humans. Moreover, research has shown that most of the functional ARGs found in WWTPs are specific to those matrices and are not widely disseminated into human populations or the environment $[38,39]$. Therefore, it is likely that, at any given time, only a small proportion of the total wastewater treatment plant (WWTP) resistome may be associated with potential adverse public health effects however; the possibility exists for the sudden mobilization and horizontal transfer of new ARGs from within the wastewater resistome which could result in additional ARGs entering the human population. It stands to reason, that assessing wastewater matrices not only for the presence of ARGs but their ability to be transferred would result in data that is more relevant to public health. Subsequently, WWTPs that reduce the fraction of clinically relevant ARGs that can be horizontally transferred would lower the probability of treated effluent waters contributing to this public health crisis. Unfortunately, obtaining a direct measurement of HGT events in wastewater has been difficult to achieve making the evaluation of treatment options more challenging. 
In water-based matrices, HGT mechanisms can be associated with either the cellular or extra-cellular fractions. The cellular fraction consists of ARGs existing within intact and/or viable bacterial cells or attached to sediments and particulates. Conversely, extracellular ARGs include bacterial DNA that has been excreted or released upon death of the organism and genes contained within viral particles. In aqueous solutions, the extracellular ARGs exist dissolved in solution whereas cell-associated ARGs can settle with other solids. The separation of cellular and extra-cellular ARGs in water can easily be achieved using centrifugation that partitions the components necessary for different HGT pathways into either the pellet or the supernatant. Specifically, HGT by conjugation would be primarily associated with viable bacteria partitioned to the solids fraction (pellet) whereas the dissolved phase (supernatant) would contain the components necessary for transformation (extra-cellular DNA) and transduction (phage particles). Quantifying the amount of ARGs in different fractions would identify where the majority of ARGs reside and consequently, which HGT pathways are likely to be involved in the transfer of ARGs at a particular treatment stage. Furthermore, such information could also be used to identify processes that are better at removing ARGs from each of the particular fractions.

This study was designed to determine the fate of dissolved and solids-associated ARGs through different stages of a tertiary WRP and to identify treatment processes that result in the best removal of ARGs. A qPCR approach was utilized to quantify two ARGs throughout wastewater treatment: the first, targets the sulfonamide resistance gene sul1, and a second targets SHV and TEM-type $\beta$-lactamase $\left(b l a_{S H V / T E M}\right)$ resistance genes. Furthermore, a pilot-scale solid media filter was used to provide a more detailed characterization of tertiary filtration on ARGs.

\section{Materials and Methods}

\subsection{Sample Collection and Processing}

Samples were obtained from a tertiary WRP designed for an average flow of 235 million $\mathrm{L} /$ day of raw sewage (daily dry weather ranges from 94 to 340 million L/day). The treatment scheme included primary sedimentation, activated sludge with nitrification and denitrification (NDN), secondary clarification (flocculation/settling), tertiary media filtration (anthracite coal/sand/gravel) and, sequential chlorine disinfection (free chlorine with a minimum required residual of $1.0 \mathrm{mg} / \mathrm{L}$ followed by chloramine with typical residual concentrations from 1.0 to $3.0 \mathrm{mg} / \mathrm{L}$ ).

Unconcentrated samples were collected in sterile one-liter Nalgene bottles. Sodium thiosulfate (one milliliter of a $10 \%$ weight/volume solution) was added to dechlorinate the water. Samples were collected at the WRP from incoming raw sewage, activated sludge, clarified secondary effluent, and disinfected final effluent. Samples were collected for each water type on at least three separate occasions.

\subsection{Collection of Hollow Fiber Filtration (HFF) Concentrated Wastewater Samples}

Antibiotic resistance genes from secondary and final effluent waters were concentrated using a one-step HFF procedure. Briefly, approximately $10^{9}$ copies of AdvIPC:pSMART plasmid were added to $100 \mathrm{~L}$ of each matrix (secondary or final effluent) then pumped through an Asahi Kasei REXEED $^{\mathrm{TM}}$-25S filter (Asahi Kasei, Oita, Japan) in a recirculation configuration with pressure within the filter maintained between four and eight psi. Bacteria and nucleic acids were eluted by recirculation of $0.05 \mathrm{M}$ Glycine containing $0.01 \%$ Antifoam A (pH 7.0) for 10 to $30 \mathrm{~min}$. New tubing was used with each sample to prevent interferences associated with reused tubing (biofilm, DNA, etc.). The original samples were collected in $50 \mathrm{~L}$ plastic carboys that had been pre-washed with hypochlorite (to remove DNA), dechlorinated, and then autoclaved. Secondary effluent was collected directly from the WRP secondary settling tank and tertiary-treated disinfected effluent (final effluent) was collected from a channel immediately after dechlorination but prior to entering the distribution system. Sodium thiosulfate was added to each carboy after collection and total chlorine concentrations were 
measured using the Hach DPD ( $N$, N-diethyl-p-phenylenediamine) colorimetric procedure (Hach Co., Loveland, CO, USA) according to method SM4500-Cl [40].

\subsection{Separation of Solids and Dissolved Fractions}

Each sample collected was separated into a solids-associated and dissolved fraction via centrifugation. Specifically, one milliliter of each sample was placed in a sterile, DNA-free tube and subjected to centrifugal force $(9600 \times g)$ for five minutes. Larger volume samples $(50 \mathrm{~mL})$ collected during the pilot-scale filtration experiments were separated by centrifugal force $(6000 \times g)$ for ten minutes. The supernatants (dissolved fraction) were decanted into a sterile DNA-free tube with the pellets (solids-associated fraction) remaining in the original tube and stored at $-80^{\circ} \mathrm{C}$ until the DNA was extracted.

\subsection{DNA Extraction}

The DNA extraction of the fractionated wastewater samples was performed with the QIAPrep ${ }^{\circledR}$ spin miniprep (solids fraction) and the QIAquick ${ }^{\circledR}$ gel extraction kit (dissolved fraction) according to the manufacturer's instructions (Qiagen Inc., Hilden, Germany). Elution volumes for the full-scale plant samples were $40 \mu \mathrm{L}$ and $30 \mu \mathrm{L}$ for the pilot-scale filtration experiments. Samples collected from the full-scale WRP were extracted on the same day that the samples were collected. Samples collected from the pilot-scale dual-media filter experiments were extracted within one week of collection. The DNA was divided into individual single-use aliquots and stored at $-80^{\circ} \mathrm{C}$.

\subsection{AdvIPC:pGEM-T and AdvIPC:pSMART Vectors}

Two plasmids were constructed to contain a DNA sequence not found in nature [41]. The synthetic DNA sequence (termed Adv IPC; synthesized by Integrated DNA Technologies Inc., Coralville, IA, USA) was inserted into the pGEM-Teasy vector (Promega Co., Madison, WI, USA) and PSMART ${ }^{\circledR}$ GC LK vector systems (Lucigen Co., Middleton, WI, USA) using standard molecular biological techniques including restriction digestion and ligation. The pGEM-Teasy vector was used with the pilot-scale filtration experiments whereas the pSMART ${ }^{\circledR}$ vector, which did not contain a $\beta$-lactamase gene, was used as an internal control for the HFF concentration of secondary and final effluents. See supplementary materials for additional sequence information and plasmid map.

\subsection{Quantitative PCR Primers/Probes and Plasmids}

Quantitative PCR primers and probes targeting the $\beta$-lactamase and sulfonamide resistance genes were used for the analysis of wastewater matrices. Additionally, qPCR assays were utilized to assess total bacterial biomass (16S rRNA gene) and to determine recovery/loss of DNA (AdvIPC) during sample concentration by HFF. A sample processing control (SPC) was used to monitor DNA extraction and qPCR inhibition in all samples analyzed. The SPC consisted of approximately $120 \mathrm{ng}$ of salmon sperm DNA (Ambion, Waltham, MA, USA) added into each sample prior to DNA extraction which was subsequently quantified by qPCR. If inhibition was identified, the sample was diluted and re-analyzed. Primer and probe sequences for all qPCRs are listed in Table 1. Each sul1 qPCR consisted of $1 \times$ SsoAdvanced ${ }^{\mathrm{TM}}$ Universal SYBR ${ }^{\circledR}$ Green Supermix (BioRad, Hercules, CA, USA), $120 \mathrm{nM}$ primer and $1 \mu \mathrm{L}$ template in a final volume of $25 \mu \mathrm{L}$. The bla $a_{S H V / T E M}$ and $16 S$ qPCRs had a final concentration of $1 \times$ SsoAdvanced $^{\mathrm{TM}}$ Universal Probes Supermix (BioRad, Hercules, CA, USA), $320 \mathrm{nM}$ each primer and probe, $3 \mu \mathrm{L}$ template in a total volume of $25 \mu \mathrm{L}$. The AdvIPC qPCR contained the same reaction constituents as the $b l a_{S H V / T E M}$ but the final probe concentration was $200 \mathrm{nM}$. The SPC qPCR consisted of $1 \times$ SsoAdvanced ${ }^{\mathrm{TM}}$ Universal Probes Supermix, $1 \mu \mathrm{M}$ each primer, $800 \mathrm{nM}$ probe, $2 \mu \mathrm{L}$ template in a final volume of $25 \mu \mathrm{L}$. The qPCR reactions were performed and analyzed using either a RotorGene (Qiagen Inc., Hilden, Germany) or LightCycler ${ }^{\circledR} 480$ (Roche, Basel, Switzerland) real-time thermocycler. The qPCR efficiency, limit of detection (LOD), and regression statistics (mean square error for the LightCycler ${ }^{\circledR} 480$ software and $\mathrm{r}^{2}$ for the RotorGene software) were determined for each reaction (see Supplementary Materials). The specificity of the bla $a_{S H V / T E M}$ PCR was confirmed 
by DNA sequence analysis of the amplified products. All primers and probes were procured from Integrated DNA Technologies (Coralville, IA, USA). Data analyses were performed using the software associated with each respective thermocycler (LightCycler ${ }^{\circledR} 480$ software version 1.5.1.62, Roche Diagnostics Corporation, Indianapolis, IN, USA, and RotorGene Q software version 2.1.0, Qiagen Inc., Hilden, Germany). Full-scale WRP samples were extracted in triplicate and each extract analyzed singularly (RotorGene) or in triplicate (LightCycler ${ }^{\circledR} 480$ analyses) by qPCR. Samples were only deemed positive if at least two of the three extractions resulted in a positive signal. Pilot-scale dual-media filtration samples were extracted and analyzed singularly (RotorGene). Turbidity readings were also taken for the full-scale WRP samples and are provided in the Supplementary Materials. The qPCR cycling conditions along with the average efficiencies and linearity data are provided in the Supplementary Materials along with additional information on the development of the qPCRs.

Table 1. Primer and probe sequences.

\begin{tabular}{|c|c|c|c|}
\hline Target & Primer/Probe & Sequence $^{1}$ & Reference \\
\hline \multirow{3}{*}{ blaSHV/TEM } & $\beta$-Lac-qPCR-F & 5'-GCCATAACCATGAGYGATAAC-3' & \multirow{3}{*}{ This study } \\
\hline & $\beta$-Lac-qPCR-R & 5'-TTATCRGCAATAAACCAGCC-3' & \\
\hline & $\beta$-Lac-qPCR Probe & 5'FAM-TCATTCAGCTCCGKTTCCCA-BHQ-1-3' & \\
\hline \multirow[b]{2}{*}{ sul1 } & sul I-FW & 5'-CGCACCGGAAACATCGCTGCAC-3' & \multirow[b]{2}{*}[42]{} \\
\hline & sul I-RV & $5^{\prime}$-TGAAGTTCCGCCGCAAGGCTCG-3' & \\
\hline \multirow{3}{*}{ Bacterial 16S rDNA } & Bac $1055 \mathrm{f}$ & 5'-ATGGCTGTCGTCAGCT-3' & \multirow{3}{*}{ [43] } \\
\hline & Bac $1392 \mathrm{r}$ & 5'-ACGGGCGGTGTGTAC-3' & \\
\hline & 16S Taq1115 & 5'-FAM-CAACGAGCGCAACCC-TAMRA-3' & \\
\hline \multirow{3}{*}{ Salmon Sperm DNA } & Samn qPCR-F & 5'-GGTTTCCGCAGCTGGG-3' & \multirow{3}{*}[44]{} \\
\hline & Samn qPCR-R & 5'-CCGAGCCGTCCTGGTCTA-3' & \\
\hline & Samn qPCR-Probe & 5'FAM-AGTCGCAGGCGGCCACCGT -BHQ-1-3' & \\
\hline \multirow{3}{*}{ AdvIPC } & Adv Hex RT-Forward & 5'-GGAYGCCTCGGAGTACCTGAG-3' & \multirow{2}{*}{ [45] } \\
\hline & Adv Hex RT-Reverse & 5'-ACiGTGGGGTTTCTRAACTTGTT-3' & \\
\hline & Adv IPC Probe & 5'Cy5-CACCGACGGCGAGACCGACTTT-BHQ2-3' & [41] \\
\hline
\end{tabular}

Note: ${ }^{1}$ The base " $i$ " designates inosine; “K" denotes $G / T$; “ $R$ " indicates $A / G$; “ $Y$ " indicates $C / T$.

\subsection{Pilot-Scale Dual-Media Filtration}

A pilot-scale dual-media filter was constructed using a PVC tube $(15.24 \mathrm{~cm}$ diameter) and the same depth of sand $(31 \mathrm{~cm})$ and anthracite coal $(61 \mathrm{~cm})$ as is used in the full-scale WRP filter beds. The flow was controlled via an electric pump and monitored with a flow meter. The filter was operated at hydraulic loading rate of 3.0 to 3.8 liters per minute $(\mathrm{L} / \mathrm{min}),\left(166 \mathrm{~L} /\left(\mathrm{min} \mathrm{m}^{2}\right)\right.$ to $\left.209 \mathrm{~L} /\left(\mathrm{min} \mathrm{m}^{2}\right)\right)$ similar to full-scale filters used at the WRP $\left(122-204 \mathrm{~L} /\left(\mathrm{min} \mathrm{m}^{2}\right)\right)$.

The pilot-scale filtration experiments were conducted using a laboratory modified plasmid (AdvIPC:pGEM-T) added to secondary effluent. Briefly, $379 \mathrm{~L}$ of clarified secondary effluent from a WRP was added to a $2271 \mathrm{~L}$ polyethylene tank and dosed with the AdvIPC:pGEM-T plasmid to achieve a final concentration of $1.95 \times 10^{8}$ copies $/ \mathrm{mL}$ in the secondary effluent. Samples were collected at a total of six locations/time points: (1) prior to the addition of plasmid, (2) after addition but before filtration, (3-5) filtrate at 20,90 and $100 \mathrm{~min}$. from the start of the filtration and (6) after backwashing the filter. Dissolved and solids-associated fractions were evaluated for exogenous plasmid concentrations in each of the samples as described above. Additionally, the filtration experiments were performed under both "dirty" and "clean" conditions: (1) using a filter that had been in service for over four weeks to simulate a bio-fouled filter, and (2) using a filter treated with high-dose chlorine to simulate a clean filter condition.

The concentration of the exogenous plasmid was determined by qPCR in each of the samples upon collection and again after chlorine treatment (10 mg/L for $45 \mathrm{~min}$ followed by dechlorination). Liquid hypochlorite was prepared using Clorox as a stock solution (5.84\% available chlorine) and diluted with ultrapure water (double reverse osmosis, carbon filtered, UV disinfected). The Clorox was stored in a light impenetrable container at room temperature. Chlorine was diluted and used within two days. Total chlorine concentrations were measured prior to treatment via the Hach DPD 
colorimetric method. Treatment doses were based on the total chlorine concentrations measured using the DPD method.

\subsection{Statistical Analyses}

Statistical analyses were performed using either Microsoft Excel 2010 (version 14.0.7190.5000, Microsoft Corporation, Redmond, WA, USA) or SigmaPlot version 11.0 software (Systat Software, Inc., San Jose, CA, USA).

\section{Results}

\subsection{Quantification of Dissolved and Solids-Associated ARGs and Bacterial 16S DNA Through Primary, Secondary and Tertiary Wastewater Treatment Processes}

The quantity of SHV/TEM type $\beta$-lactamase genes $\left(b l_{\text {SHV/TEM }}\right)$ and sul1 sulfonamide resistance genes was determined by qPCR analysis for both the solids-associated and dissolved fractions from each sample. Additionally, a qPCR targeting the $16 S$ rRNA gene DNA (16S rDNA) was used to estimate total bacterial biomass in each water type analyzed. The average qPCR efficiencies were 95\%, $86 \%$ and $99 \%$ with LODs of 70,6 , and 57 copies / $\mu \mathrm{L}$ for the bla $a_{S H V / T E M}$, sul1, and $16 S$ rDNA reactions, respectively (Supplementary Materials).

\subsubsection{Antibiotic Resistance Gene Concentrations throughout a Full-Scale WRP}

All three gene targets were readily detected in the raw sewage however; concentrations of bla $a_{S H V / T E M}$ in the secondary effluent, and sul 1 and $b l a_{S H V / T E M}$ in the final effluent were found to be below the detection limit of the method in all unconcentrated samples analyzed $(n=6)$. In response, a HFF method was used to concentrate ARGs from secondary and final effluents (by approximately 200-fold). A laboratory modified plasmid (AdvIPC:pGEM-T) added to each final effluent sample prior to concentration was used to evaluate recovery of dissolved DNA. The results showed an average recovery after concentration of $57 \%$ which demonstrated that the method could be used as an effective means to concentrate ARGs in these waters. Consequently, sul1 was detected within the quantifiable range in HFF concentrated secondary and final effluents and bla $a_{S H V / T E M}$ was detected in the concentrated secondary effluent but remained below detection in all final effluent samples. This demonstrated that the HFF procedure provided increased sensitivity for ARGs and permitted the quantitative assessment of ARGs in secondary and final effluents.

The quantities of both ARGs and the 16S DNA decreased through each stage of treatment in the dissolved fractions (Figure 1 and Table 2). In particular, sul1 genes were reduced by $1.46 \log _{10}$ (raw to activated sludge), $1.28 \log _{10}$ (activated sludge to secondary effluent) and $2.05 \log _{10}$ (secondary effluent to final effluent). Reductions were also observed for the bla $a_{S H V / T E M}$ genes: $0.83 \log _{10}$ (raw to activated sludge), $2.01 \log _{10}$ (activated sludge to secondary effluent) and $\geq 0.24 \log _{10}$ decrease (secondary effluent to final effluent; $b a_{S H V / T E M}$ gene concentrations in all HFF concentrated final effluent samples were below the detection limit, resulting in the "greater than" value). This data indicates that a large proportion of the dissolved ARG DNA was degraded or removed during the various treatment processes.

Table 2. Log reductions in dissolved ARGs and $16 S$ total bacterial rDNA during wastewater treatment.

\begin{tabular}{|c|c|c|c|c|c|}
\hline Gene Target & Raw to AS ${ }^{1}$ & Raw to $\mathrm{SE}^{1}$ & Raw to $\mathrm{FE}^{1}$ & AS to $S E^{1}$ & $S E$ to $\mathrm{FE}^{1}$ \\
\hline$b l a_{S H V / T E M}$ & $0.83^{3}$ & 2.84 & $\geq 3.08^{2}$ & 2.01 & $\geq 0.24^{2}$ \\
\hline sul1 & 1.46 & 2.74 & 4.79 & 1.28 & $2.05^{3}$ \\
\hline $16 \mathrm{~S}$ & 0.63 & 1.24 & 3.99 & 0.61 & 2.76 \\
\hline
\end{tabular}

Notes: ${ }^{1}$ AS: activated sludge; SE: HFF concentrated secondary effluent; FE: HFF concentrated final effluent; ${ }^{2}$ All samples tested were below the detectable limit of the qPCR and were assigned the value of the assay's detection limit for log removal calculations; ${ }^{3}$ Three of nine bla $a_{S H V / T E M}$ AS replicates and one of six sul1 FE replicates were negative by qPCR analysis. Negative samples were assigned the LOD in log removal calculations. 


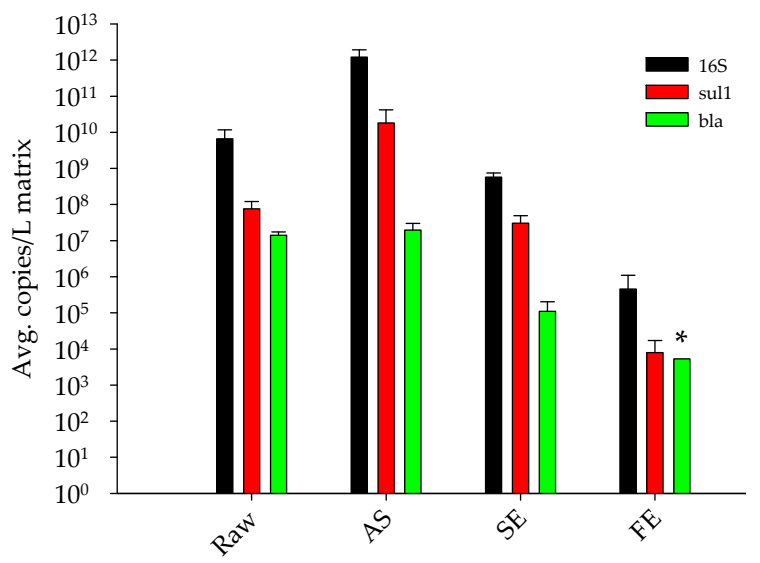

(a)

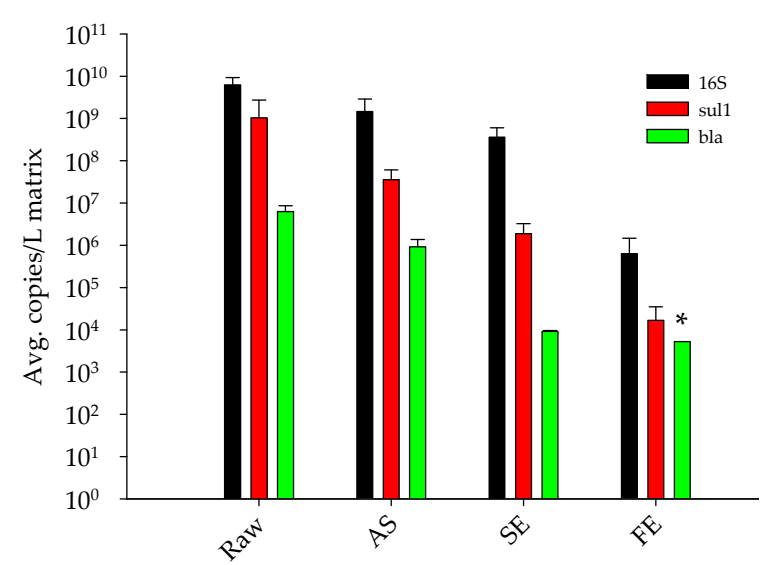

(b)

Figure 1. Concentrations of $b l a_{S H V / T E M}$, sul1, and bacterial $16 S$ rDNA in different wastewater treatment matrices. (a) The solids-associated qPCR concentrations; (b) The dissolved fraction qPCR concentrations. Error bars represent one standard deviation from the mean. Bar colors indicate the following samples, black: bacterial 16S, red: sul1, green: $b l a_{S H V / T E M}$. The ${ }^{*}$ symbol denotes matrices where all samples analyzed were below the LOD with the corresponding bar representing the detection limit for that particular gene. Raw: raw sewage, AS: activated sludge, SE: secondary effluent, FE: disinfected final effluent.

With reference to the solids-associated fraction, the $16 S$, bla $a_{S H V / T E M}$, and sul1 genes all increased between the raw sewage and activated sludge stages (Figure 1 and Table 3) but not to the same extent. The sul 1 and $16 S$ DNA exhibited a similar rise $\left(2.38\right.$ vs. $\left.2.26 \log _{10}\right)$ whereas the bla $a_{S H V / T E M}$ was substantially smaller $\left(0.14 \log _{10}\right)$. Specifically, there was approximately an order of magnitude difference between the increase in the bla $a_{S H V / T E M}$ and sul1 $(0.14 \log$ vs. $2.38 \mathrm{log}$, Table 3$)$ or the $16 \mathrm{~S}$ DNA (0.14 vs. 2.26, Table 3). These differences between the increase in bla ${ }_{S H V / T E M}$ and either the sul1 or the 16S DNA were statistically significant (ANOVA $p \leq 0.05$; Supplementary Materials). While the sul1 did show a slightly larger increase compared to the 16S DNA, it was not statistically significant (ANOVA $p \geq 0.05$; Supplementary Materials). The amount of increase was specific to the individual ARG, suggesting that the ARG distributions among bacteria in the activated sludge differ.

Table 3. Log reductions in solids-associated ARGs and 16S bacterial rDNA during wastewater treatment.

\begin{tabular}{cccccc}
\hline Gene Target & Raw to AS $^{\mathbf{1}}$ & Raw to SE $^{\mathbf{1}}$ & Raw to FE $^{\mathbf{1}}$ & AS to SE $^{\mathbf{1}}$ & SE to FE $^{\mathbf{1}}$ \\
\hline bla $_{\text {SHV/TEM }}$ & -0.14 & 2.11 & $\geq 3.42^{2}$ & 2.25 & $\geq 1.31^{2}$ \\
sul1 & -2.38 & 0.40 & 3.98 & 2.78 & $3.58^{3}$ \\
$16 S$ & -2.26 & 1.06 & 4.16 & 3.32 & $3.10^{3}$ \\
\hline
\end{tabular}

Notes: ${ }^{1}$ AS: activated sludge; SE: HFF concentrated secondary effluent; FE: HFF concentrated final effluent; ${ }^{2}$ All samples tested were below the detectable limit of the qPCR and were assigned the value of the assay's detection limit for log removal calculations; ${ }^{3}$ Three of six sul1 FE replicates and two of six $16 S$ AS replicates were negative by qPCR analysis. Negative samples were assigned the LOD in log removal calculations.

The complete WRP treatment process (from raw to final effluent) resulted in an overall decrease in sul1 genes by $4.79 \log _{10}$ in the dissolved fraction and $3.98 \log _{10}$ in the solids fractions with similar reductions observed in the total bacterial biomass (Tables 2 and 3). The bla $a_{S H V / T E M}$ concentrations were reduced by greater than three $\log _{10}$ throughout the treatment process although, it was not possible to determine exactly how much more than three $\log _{10}$ because all final effluent samples were below the LOD and thus the method's detection limit was used to calculate the reductions (Tables 2 and 3). Tertiary filtration/disinfection produced the largest stage to stage decrease in sul1 (both fractions) and $16 S$ rDNA (dissolved fraction). Moreover, sul1 genes are some of the most prevalent ARGs found 
in wastewater, yet despite being concentrated over 200-fold by HFF, half of the solids fraction (three of six) and one of the dissolved final effluent samples remained below the LOD. This indicated that the tertiary filtration and disinfection stage was instrumental in achieving the large ARG reductions observed over the complete treatment process (Figure 1 and Tables 2 and 3).

The qPCR analyses from the full-scale WRP samples demonstrated that the sul1 genes were consistently found in higher concentrations compared to the bla $a_{S H V / T E M}$ for all treated and untreated wastewater samples in both the solids and dissolved fractions (Figure 1). The different sample types had different proportions of ARGs associated with each fraction. The raw sewage, activated sludge and secondary effluent solids fractions on average contained higher counts of both ARGs compared to the dissolved fraction (Figure 2) although, one of the raw sewage replicates did show a larger sul1 concentration in the dissolved fraction. The highest proportion of solids-associated ARGs occurred in the activated sludge with over 100-fold more ARG observed in the solids fraction compared to the dissolved ARGs (Figure 2). In comparison, the tertiary-treated effluent contained nearly equal amounts of dissolved and solids-associated ARGs (Figure 2). The solids-associated to dissolved ARG ratio decreased successively from the activated sludge through to the final effluent (Figure 2). The larger proportion of dissolved ARGs in the final effluent may be the result of DNA released during chlorine disinfection.

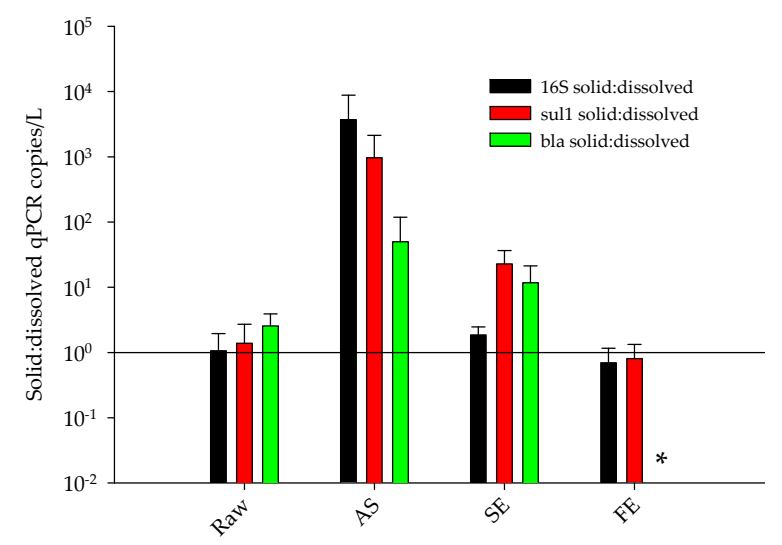

Figure 2. The proportion of ARGs observed in the solids and dissolved fractions during different wastewater treatment stages. The plot shows the ratio of solids to dissolved qPCR copies for total

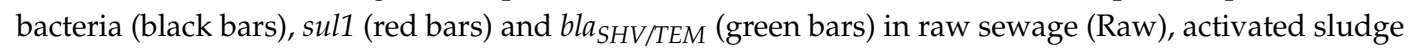
(AS), secondary effluent (SE), and disinfected final effluent (FE). The bars represent the average of at least three separate samples with error bars indicating one standard deviation from the mean. The horizontal line is provided for reference and denotes equal ratios of solids and dissolved genes. The * symbol indicates that $b l a_{\text {SHV/TEM }}$ concentrations in the final effluent were all below the LOD.

\subsubsection{Determination of Total Bacteria Biomass Concentrations in Different Wastewater Treatment Processes by qPCR}

The total bacterial biomass concentrations were estimated using qPCR targeting a region of the $16 \mathrm{~S}$ rRNA gene that is well conserved among bacterial species [43]. Native solids and dissolved fractions (not concentrated by HFF) were all positive for the $16 \mathrm{~S}$ rDNA qPCR target (Figure 1). The proportion of solids and dissolved $16 \mathrm{~S}$ rDNA were similar in the raw sewage, secondary and final effluents with a large increase occurring in the solids-associated ARGs in the activated sludge samples (Figure 2). The dissolved $16 S$ rDNA decreased in concentration at each consecutive stage from raw sewage to the final effluent (Figure 1). In contrast, an increase in solids-associated 165 rDNA was observed between the raw and activated sludge with reductions occurring in the secondary and final effluents (Figure 1; Tables 2 and 3). Viable bacterial concentrations are known to increase during the activated sludge stage of treatment and the increase in the solids-associated 165 qPCR copies coupled with the concurrent decrease in dissolved 16S DNA suggested that the viable fraction of bacterial cells did indeed partition 
to the solids-associated fraction. The total reduction in 165 DNA was approximately four- $\log _{10}$ from the raw sewage to final effluent concentrations for both fractions similar to what was observed with the sul1 (Tables 2 and 3).

\subsection{Tertiary Wastewater Treatment Processes did not Result in Positive Selection for bla $a_{S H V / T E M}$ or sul1 ARGs}

Examination of the qPCR data from different WRP treatment stages provided no evidence that the ARGs analyzed in this project were being selected for during the treatment process. Normalizing the ARG concentrations to the total bacterial biomass (16S bacterial rDNA qPCR) provided an assessment of how the concentration of each gene changed in relation to the total bacterial population during wastewater treatment. The solids fractions were used to represent intact bacteria in each water type. The ratio of ARG: $16 S$ rDNA was calculated for each matrix and used to determine if the ARGs increased or decreased during wastewater treatment.

The sul1 and 16S gene concentrations trended together in the solids fractions of each matrix tested, resulting in sul1:16S ratios that were within one order of magnitude for all water types (Table 4). The differences were not statistically significant (see supplementary material) with the exception of a decrease in the ratio from secondary effluent to final effluent (Table 4). Conversely, the solids fraction bla $a_{S H V / T E M}: 16 S$ ratios decreased by over two orders of magnitude between the raw sewage (range: $1.7 \times 10^{-3}$ to $1.4 \times 10^{-2}$ ) and activated sludge (range: $4.2 \times 10^{-6}$ to $4.3 \times 10^{-5}$; Table 4 ). This indicated that the total bacterial biomass in the activated sludge contained a significantly smaller proportion of the $b l a_{S H V / T E M}$ gene compared to the raw sewage (Table 4); the difference was statistically relevant ( $t$-test $p \leq 0.05$; Supplementary Materials) suggesting its presence was not being selected for during the biological phase of treatment. In the secondary effluent, the bla $a_{S H V / T E M}$ ratio was slightly higher than the activated sludge (difference not statistically significant, $t$-test $p \geq 0.05$; Supplementary Materials) however; the secondary effluent ratio (range: $1.1 \times 10^{-4}$ to $2.9 \times 10^{-4}$ ) was still significantly lower (by 1.52 log units) compared to the raw sewage (Table 4 and Supplementary Materials). The qPCR data from final effluent samples showed that all bla ${ }_{S H V / T E M}$ were below the LOD and therefore ratios could not be accurately calculated. Overall, the qPCR data demonstrated that, not only did the quantity of ARGs decrease during WRP treatment but, so did the proportion of bacteria carrying the $b l a_{S H V / T E M}$

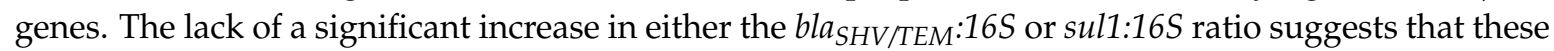
ARGs are not being selected for throughout the treatment process. The dissolved fractions, although unlikely to contain significant amounts of intact bacteria, also did not show any increase in ARG:16S ratio between the raw and secondary or final effluents (Table 4).

Table 4. Ratio of ARGs to bacterial $16 S$ qPCR concentrations in wastewater matrices (average \pm standard deviation).

\begin{tabular}{ccccc}
\hline ARG:16S $^{\mathbf{1}}$ & $\begin{array}{c}\text { Raw Sewage } \\
(\boldsymbol{n}=\mathbf{3})\end{array}$ & $\begin{array}{c}\text { Activated Sludge } \\
(\boldsymbol{n}=\mathbf{9})\end{array}$ & $\begin{array}{c}\text { Secondary Effluent } \\
(\boldsymbol{n}=\mathbf{3})^{\mathbf{2}}\end{array}$ & $\begin{array}{c}\text { Final Effluent } \\
(\boldsymbol{n}=\mathbf{6})^{\mathbf{3}}\end{array}$ \\
\hline bla:16S solids & $5.8 \times 10^{-3} \pm 7.1 \times 10^{-3}$ & $2.0 \times 10^{-5} \pm 1.4 \times 10^{-5}$ & $1.7 \times 10^{-4} \pm 9.8 \times 10^{-5}$ & \\
sul1:16S solids & $2.0 \times 10^{-2} \pm 1.7 \times 10^{-2}$ & $1.3 \times 10^{-2} \pm 8.3 \times 10^{-3}$ & $6.3 \times 10^{-2} \pm 5.3 \times 10^{-2}$ & $2.9 \times 10^{-2} \pm 2.9 \times 10^{-2}$ \\
bla:16S dissolved & $1.1 \times 10^{-3} \pm 5.8 \times 10^{-4}$ & $3.2 \times 10^{-3} \pm 4.2 \times 10^{-3}$ & $3.3 \times 10^{-5} \pm 1.7 \times 10^{-5}$ & $\mathrm{BD}$ \\
sul1:16S dissolved & $2.2 \times 10^{-1} \pm 3.8 \times 10^{-1}$ & $4.8 \times 10^{-2} \pm 6.0 \times 10^{-2}$ & $8.2 \times 10^{-3} \pm 6.7 \times 10^{-3}$ & $2.6 \times 10^{-2} \pm 2.9 \times 10^{-2}$ \\
\hline
\end{tabular}

Notes: ${ }^{1}$ Designates the ARG ratio. "Solids" term indicates the concentrations in the pelleted fraction for each matrix. "Dissolved" term indicates the concentrations in the supernatant fractions for each matrix; ${ }^{2}$ Samples were concentrated via HFF prior to DNA extraction; ${ }^{3}$ Samples were collected after dual media filtration of clarified secondary effluent and chlorine disinfection. All samples were concentrated by HFF prior to DNA extraction. $\mathrm{BD}$ : All concentrations for bla $_{S H V / T E M}$ in the final effluent were below the detection limit of the assay.

\subsection{Evaluation of Tertiary Filtration and Disinfection Processes for the Removal of ARGs}

Analysis of full-scale WRP samples demonstrated that $\beta$-lactamase gene concentration was below the LOD in all HFF concentrated final effluent samples (from both fractions) and sul1 was not detected in the solids fraction in half of the final effluent samples. The lack of detection of ARGs in the final effluent even after HFF concentration suggested that large amounts of dissolved ARGs were being 
removed during the tertiary filtration and/or chlorination processes. A closer inspection of the tertiary filtration and chlorine disinfection was performed using a pilot-scale dual-media filter which provided a controlled filtration process that mimicked the configuration and operation of the full-scale WRP filters. The pilot-scale filters allowed precise control over operational parameters as well as the ability to characterize the removal of ARG containing DNA. Specifically, a known quantity of a laboratory modified plasmid was added to a defined volume of secondary effluent (379 L) which was then pumped into the pilot-scale filter unit at a flow rate similar to the full-scale filters used at the WRP. The plasmid concentration was measured in samples collected before and after filtration using qPCR. Given that the concentration of modified plasmid added to the secondary effluent was known, and that the volume applied to the filter was defined, the amount of plasmid removed per unit volume could be determined. In addition, bench-scale chlorination experiments were conducted on the pre- and post- filtration samples to determine the effect of chlorination on the exogenous plasmid.

The presence of naturally occurring ARGs in secondary effluent precluded the use of an ARG-specific qPCR for these experiments. Therefore, a laboratory-modified plasmid was constructed which contained a $b l a_{S H V / T E M}$ ARG as well as an exogenous DNA sequence that does not occur in wastewater. A qPCR assay targeting the exogenous sequence (not the ARG) was used to specifically quantify the laboratory-modified plasmid through the filtration and disinfection experiments thus, avoiding any interference by naturally occurring genes.

Shortly after addition of the modified plasmid to the secondary effluent, a majority of the plasmid was detected in the dissolved fraction with a smaller portion present in the solids-associated fraction. In particular, samples collected approximately ten minutes after addition (but prior to filtration) showed the plasmid concentration in the dissolved fraction averaged $1.23 \times 10^{8}$ copies $/ \mathrm{mL}(n=7)$ compared to $8.79 \times 10^{6}$ copies $/ \mathrm{mL}$ in the solids-associated fraction (Supplementary Materials). The difference in plasmid concentrations between the two fractions was statistically significant ( $t$-test $p$-value 0.007$)$. This demonstrates that a small portion of the free DNA (less than $10 \%$ ) had a propensity to associate with solid particles in secondary effluent.

The pilot-scale filtration experiments showed that tertiary filtration coupled with chlorine disinfection removed plasmid ARGs better than chlorination alone. Reduction in plasmid concentration by the filtration and chlorination processes was determined by subtracting the log transformed pre-filtration data from the post-filtration sample data with and without chlorine treatment. The decrease in plasmid concentration due solely to the filtration process was determined by analyzing samples before and after tertiary filtration without chlorine treatment. In the solids-associated fraction, this resulted in a $0.7 \pm 0.5 \log _{10}$ reduction $(n=7$, Table 5$)$ after approximately 341 of the $379 \mathrm{~L}$ had been filtered. Similar reductions of $0.9 \pm 0.3 \log _{10}$ were observed in the dissolved partition (Table 6). In contrast, chlorination caused in a more dramatic reduction in both the dissolved and solids-associated plasmid concentrations. The chlorine-treated secondary effluent (prior to filtration) reduced the dissolved plasmid concentration by $3.4 \pm 1.6 \log _{10}$ and the solids-associated by $2.6 \pm 1.4 \log _{10}$ (Tables 5 and 6, Figure 3). Even larger plasmid reductions were observed after chlorine treatment of the filtered samples. In particular, the plasmid concentrations were reduced to below detectable limits in all of the tertiary filtered effluents treated with chlorine (samples collected after $90 \mathrm{~min}$. of filtration, $n=7$ ), resulting in average log removal values of greater than 5.2 and $4.4-\log _{10}$ for the dissolved and solids-associated fractions, respectively (Tables 5 and 6, Figure 3). The LOD was used to calculate the log removal values for samples below detection thus, the data represent the minimum removal that was achieved; the actual reductions may be substantially larger. Comparing the effects of chlorine on the pre- and post-filtered samples, after accounting for the amount that was removed by the filter alone, showed that the filtered chlorinated samples removed approximately an order of magnitude or greater of plasmid ARGs compared to the pre-filtered chlorinated samples (Tables 5 and 6). These data indicate that combining filtration and chlorination processes produced a synergistic effect resulting in additional removal of extracellular ARGs compared to chlorine treated pre-filtered samples. 


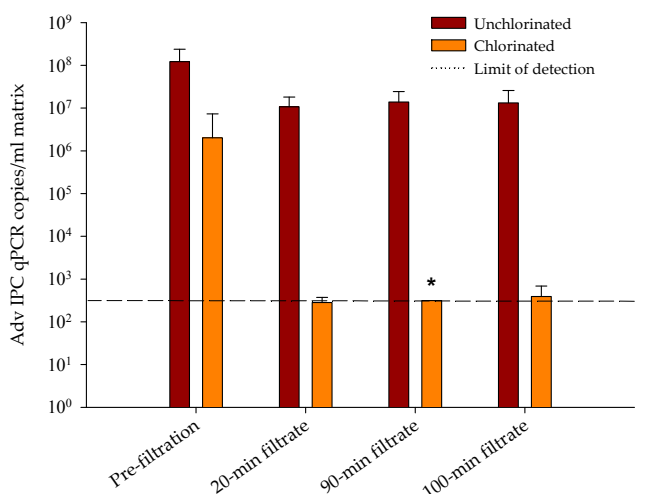

(a)

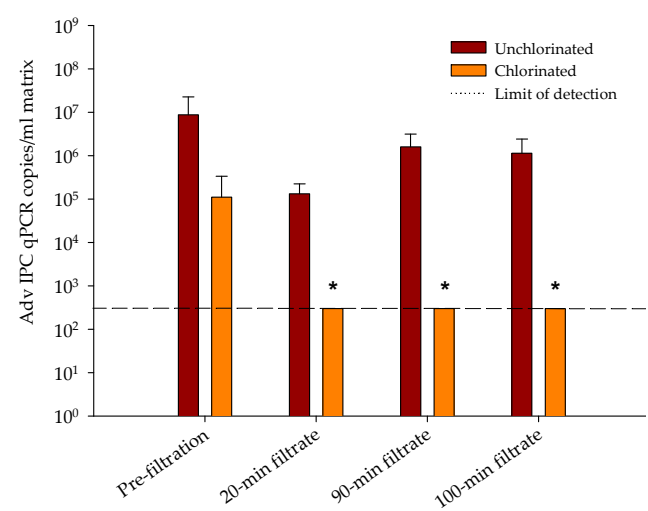

(b)

Figure 3. The removal of an antibiotic resistance plasmid by filtration and chlorination processes. An exogenous laboratory-modified plasmid was added into secondary effluent from a WRP and filtered through a dual-media pilot-scale filter with or without chlorine treatment. (a) dissolved fraction qPCR data (b) solids-associated fraction qPCR data. Pre-filtration refers to samples taken after addition of the plasmid but prior to filtration. The 20,90 and $100 \mathrm{~min}$. filtrate designations refer to effluent coming through the filter 20,90 and $100 \mathrm{~min}$. after the start of filtration. The data represent the average of at least seven independent filtration experiments. The maroon bars represent the unchlorinated samples and the orange bars represent the chlorine treated samples, the dashed line represents the limit of detection for the assay. Error bars represent one standard deviation from the mean. The * symbol indicates that all replicate samples were below the LOD of the assay with the corresponding bar representing the detection limit value.

Table 5. Comparison of exogenous plasmid concentrations in the solids fraction before and after filtration and/or disinfection.

\begin{tabular}{ccc}
\hline Sample $^{\mathbf{1}}$ & ${\text { Average Log Difference }(n=7)^{\mathbf{2}}}^{{ }^{2}}$ & Rank Sum Test $p$-Value $^{\mathbf{3}}$ \\
\hline SE vs. chlorinated filtrate & $>4.4 \pm 0.6$ & $<0.001$ \\
SE vs. chlorinated SE & $2.6 \pm 1.4$ & $<0.001$ \\
SE vs. filtrate (no chlorine) & $0.7 \pm 0.5$ & 0.097 \\
Chlorinated SE vs. chlorinated filtrate & $>1.8 \pm 1.6$ & 0.004 \\
Filtrate vs. chlorinated filtrate & $>3.7 \pm 0.6$ & $<0.001$
\end{tabular}

Notes: ${ }^{1}$ Statistical comparisons were performed on the concentrations of plasmids between two different matrices. SE: secondary effluent prior to filtration but after plasmid addition; filtrate: secondary effluent collected after it had passed through the filter (90-min time point). "Chlorinated" designates the samples were treated with $10 \mathrm{mg} / \mathrm{L}$ chlorine for $45 \mathrm{~min}^{2}{ }^{2}$ The qPCR data (copies/mL) was log transformed for each sample and the water type listed. In each case the transformed data from the water type listed second was subtracted from the first type listed to yield the log difference. The average of the seven individual log differences is shown with the standard deviation; ${ }^{3}$ Statistical relevance between the two matrices using the Mann-Whitney rank sum test was indicated by $p<0.05$.

Table 6. Comparison of exogenous plasmid concentrations in the dissolved fraction before and after filtration and/or disinfection.

\begin{tabular}{ccc}
\hline Sample $^{\mathbf{1}}$ & ${\text { Average Log Difference }(\boldsymbol{n}=\mathbf{8})^{\mathbf{2}}}^{\mathbf{2}}$ & Rank Sum Test $\boldsymbol{p}$-Value $^{\mathbf{3}}$ \\
\hline SE vs. chlorinated filtrate & $>5.2 \pm 0.9$ & $<0.001$ \\
SE vs. chlorinated SE & $3.4 \pm 1.6$ & $<0.001$ \\
SE vs. filtrate (no chlorine) & $0.9 \pm 0.3$ & 0.007 \\
Chlorinated SE vs. Chlorinated filtrate & $>1.8 \pm 1.8$ & 0.038 \\
Filtrate vs. chlorinated filtrate & $>4.3 \pm 0.8$ & $<0.001$ \\
\hline
\end{tabular}

Notes: ${ }^{1}$ Statistical comparisons were performed between two different matrices.SE: secondary effluent prior to filtration but after plasmid addition; filtrate: secondary effluent collected after it had passed through the filter. "Chlorinated" designates the samples were treated with $10 \mathrm{mg} / \mathrm{L}$ chlorine for $45 \mathrm{~min} ;{ }^{2}$ The qPCR data (copies $/ \mu \mathrm{L}$ ) was log transformed for each sample and subtracted between two treatments to yield the log difference. The averaged result of the eight individual log differences is shown with the standard deviation; ${ }^{3}$ Statistical relevance between the two matrices using the Mann-Whitney rank sum test was indicated by $p<0.05$. 
Gross inhibition of target amplification, as determined using the salmon sperm DNA, was not detected in any of the reactions. In addition, the control samples collected before the addition of the plasmid all tested negative for the AdvIPC target amplicon indicating that the unique sequence was indeed not present in this matrix. Finally, no difference was found with regards to plasmid removal, between the experiments performed after the filters had been in service for greater than two weeks (bio-fouled conditions) or after the filters had been treated with a high dose of chlorine to remove fouling matter (data not shown).

\section{Discussion}

Antibiotic resistance genes have been identified as contaminants of emerging concern in environmental matrices and could be subject to regulatory monitoring requirements in the future. However, ARGs have been found in every environment on earth and their presence alone does not necessarily signify a major public health concern. The primary factors which have led to the current public health crisis with respect to antibiotic resistance are the horizontal transfer of resistance genes to antibiotic susceptible bacteria coupled with the prodigious use of antibiotics which provided a positive selective pressure resulting in the rapid dissemination of AR across the globe. Therefore, it becomes important to not only identify clinically relevant ARGs in the environment but to also characterize their ability to be transferred between bacteria.

The ARGs chosen for this study represent both clinically relevant and transmissible genes suggesting they are appropriate indicators of ARGs in wastewater. In particular, $\beta$-lactams are some of the most prescribed antibiotics worldwide [46]; moreover, bla ARGs are prevalent in human pathogens as well as in wastewater $[47,48]$ and have shown the ability to undergo HGT [49]. The sul1 gene is known to be associated with class I integrons on conjugative plasmids $[50,51]$ and is one of the most abundant ARGs in wastewater [52].

Previous data combined from several reports show that concentrations of ARGs can vary throughout wastewater treatment depending on the ARG studied, the extent of treatment, geographical location, and operational parameters (reviewed in [52]). The results presented herein show that the concentrations of bla $a_{S H V / T E M}$ and sul1 were similar to what has been reported by others for raw wastewater, activated sludge, secondary and tertiary effluent although the sul1 concentrations were slightly higher in the activated sludge than what has been reported previously [52]. The tertiary WRP examined in this study produced ARG reductions of approximately four- $\log _{10}$ in the final disinfected effluent compared to the raw sewage concentrations which are some of the largest overall reductions reported for activated sludge-type WWTPs [53-57]. The full extent of the $\beta$-lactamase reductions in the disinfected final effluent from the full-scale WRP, could not be precisely quantified because the values for all samples analyzed were below the detectable limit of the qPCR assay.

Although sul1 and bla $a_{S H V / T E M}$ concentrations were greatly reduced after activated sludge treatment, the ARGs were still present in both fractions in the secondary effluent. In contrast, the $b l a_{S H V / T E M}$ genes could not be detected in tertiary-treated final effluent (after chlorination) even upon concentrating the water samples over 200-fold. The sul1 gene was detected in higher numbers throughout each of the treatment stages compared to the $b l_{S H V / T E M}$ yet, was only detected in three of six concentrated final effluent samples for the solids fraction and five of six dissolved fraction samples. This indicated that substantial removal occurred during the tertiary filtration and disinfection processes (solids: $>2-\log _{10}$ and dissolved: $>3-\log _{10}$ reduction). Pilot-scale filtration experiments were incorporated to further study the media filtration and disinfection processes. The results indicated that tertiary filtration coupled with chlorine disinfection provided a synergistic benefit with respect to removal of ARGs compared to chlorination alone. More specifically, chlorine mediated reduction of ARGs was more effective on filtered effluents compared to non-filtered effluents. The increased effectiveness of the chlorine in the filtered water may reflect the removal of substances that increase chlorine demand during filtration. As a consequence, more chlorine would be available in the filtered water compared to the unfiltered secondary effluent resulting in greater degradation of the 
ARGs. A previous report found that disinfection of tertiary-treated effluent waters provided less than a one- $\log _{10}$ reduction in ARG concentration [55]. Several factors may explain the discrepancy between the results presented here and Munir et al. (2011): the WRP studied here incorporated biological ammonia removal through a nitrification and denitrification process lowering ammonia levels in the effluent resulting in less chloramine formation. Therefore, the removal rates documented here may differ for WWTPs that do not incorporate ammonia removal processes. Specifically, other investigators have reported that chloramines are less effective in reducing ARG concentrations in wastewater compared to free chlorine [58]. It should be noted that the effects of ammonia on ARG removal were not specifically evaluated as part of this project. Additionally, the geographic locations of the WWTPs differed in the two studies and the operational parameters were not reported; both factors could have contributed to differences in the presence and removal of ARGs. Taken together, these data indicate that WWTPs that include the use of tertiary filtration with disinfection can provide additional ARG reductions and thereby further minimize any potential public health and environmental impacts compared to those without filtration.

The pilot-scale tertiary filtration and chlorine disinfection experiments resulted in a removal of at least five $\log _{10}$ of dissolved ARG plasmid. Very little ARG removal was attributed to the filtration process itself (less than $0.9 \log _{10}$ ) whereas the chlorinated, filtered effluent decreased the ARG concentration to undetectable limits, signifying a substantial role for chlorine in the overall removal. Treatment of secondary effluents with chlorine successfully reduced ARG concentrations however; tertiary filtration was shown to enhance the chlorine mediated removal of ARGs and provided at least an additional order of magnitude more reduction compared to chlorinated secondary effluent alone. The full-scale WRP data showed an average removal of greater than two $\log _{10}$ between secondary and tertiary filtered, disinfected effluents indicating that further optimization of the filtration and disinfection processes could produce additional ARG reductions. The use of pilot-scale processes offered some experimental advantages not available at the full-scale level. In particular, the pilot-scale filtration permitted the study of ARG removal using a single homogenous plasmid added into the secondary effluent immediately prior to filtration whereas, the full-scale plant experiments detected ARGs from multiple sources of DNA (plasmids, genomic, phage, etc.) that could interact with elements present throughout the treatment process. Furthermore, chlorination of the pilot-scale samples was performed under controlled conditions in the laboratory where the precise concentration and contact time were monitored along with the use of fresh liquid chlorine thus, maximizing its oxidative potential. Future studies focused on the optimization of ARG removal by full-scale filtration and chlorination processes would provide additional information on how to further reduce these constituents.

Currently, it is difficult to directly assess the total HGT activity in wastewater ecosystems. While there are culture-based methods available that can approximate transfer in particular model organisms or by certain mechanisms, they have drawbacks [59]. The use of non-culture-based methods such as PCR offer the ability to identify ARGs and transmissible elements from essentially all sources in a sample and because HGT mechanisms are associated with cellular or extracellular fractions, PCR analysis of ARGs in each fraction can provide information concerning which HGT pathways have a greater likelihood of leading to ARG transfer. This approach assumes that higher concentrations of ARGs in a particular fraction correlate with an increased chance of HGT occurring by the pathways associated with each fraction. In support of this, transformation rates in water have been shown to increase with increasing gene concentrations [60] and the same logic would be expected to apply with transduction-mediated HGT. With respect to the solids-associated fraction, conjugation rates in water have been shown to be dependent on the number of cells containing the transferrable gene [61].

While not a direct assessment of HGT, analyzing the cellular and extracellular fractions for ARGs provided some insight into where these genes reside during different treatment stages as well as which HGT mechanisms may have a higher probability of occurring in each water type. For example, the ratio of solids to dissolved ARGs was at least 100-fold higher in the activated sludge compared to the tertiary-treated, disinfected effluent, which would suggest that HGT via conjugation would be 
more likely to occur in the activated sludge compared to the final effluent. Note that there are multiple factors that can affect the horizontal transfer of genes in the environment and while the fractionation experiments give some insight into the probability of one transfer pathway occurring over another it is not a direct analysis of HGT. Given the importance of HGT with regard to spread of AR, a more thorough study targeting HGT in these waters would be beneficial.

The concentrations of dissolved and solids-associated ARGs differed between the treatment processes. The dissolved concentrations of both ARGs were highest in the raw sewage and showed reductions at each successive stage of treatment (raw $>$ activated sludge $>$ secondary effluent $>$ tertiary effluent). In contrast, the concentrations of both ARGs and 16S DNA in the solids fraction increased in the activated sludge compared to the raw sewage. The sul1 and $16 S$ genes increased in a similar fashion while the $b l a_{S H V / T E M}$ demonstrated a smaller increase than the other two genes (statistically significant) suggesting the genes may be present in separate microbial populations. This trend was not observed in subsequent stages as both ARGs were reduced substantially in the solids fraction of the secondary and final effluents (raw < activated sludge $>$ secondary effluent $>$ final effluent).

These results would be consistent with a model in which ARG concentrations increase in conjunction with the expansion of microbial populations during the biological phase of treatment (activated sludge) followed by a decrease in the amount of solids associated ARGs in the secondary effluent resulting from floc settling and solids removal. Finally, an increase in the percentage of dissolved ARGs observed after tertiary filtration and disinfection could result from the chlorine-mediated destruction of bacterial cells releasing additional DNA in the aqueous fraction. Reductions in viable indicator bacterial concentrations after tertiary filtration and disinfection have been well documented and, coupled with data that demonstrate the presence of extracellular Bacteroides DNA in the absence of the viable bacteria after wastewater treatment [62], lend support to this theory. Additionally, a recent disinfection study using enterococci containing the vanA resistance gene demonstrated that vanA DNA could be detected after chlorination of secondary effluent when the concentration of viable enterococci was reduced to below detectable limits [63]. What effect, if any, the release of dissolved DNA has on the presence and dissemination of ARGs in waters that receive treated effluents is currently unknown.

Presently there is no consensus as to whether ARGs are selected for or against during wastewater treatment with published reports illustrating both scenarios [17,20,24,54,64-69]. However, the activated sludge treatment stage in particular, has been proposed as a potential source for ARG transfer [56]. This study examined samples from each stage of treatment and evaluated the data for positive and negative selection by comparing the two target ARGs to the number of $16 S$ rDNA genes (an indicator of the total bacterial biomass). The ratio of sul1 to $16 \mathrm{~S}$ did not change significantly throughout each stage of treatment (for both fractions) suggesting this ARG was neither selected for or against. The $b l a_{S H V / T E M}: 16 S$ ratio in the solids fraction decreased between the raw sewage and activated sludge matrices in a statistically relevant manner indicating that the number of bla SHV/TEM genes in relation to the total bacterial biomass went down compared to the raw sewage. The solids fraction ratio increased slightly in the secondary effluent compared to the activated sludge (not statistically significant) but was still below the ratio observed in the raw sewage. A comparison of the dissolved fractions showed little change between the raw and activated sludge bla $a_{S H V / T E M}: 16 S$ but decreased significantly in the secondary effluent (statistically significant). The fact that the ARGs did not increase at a significantly larger rate than the total bacterial population suggests that they were not selected for during the treatment processes with respect to the overall bacterial populations present at each stage. In total, the data showed no evidence that the two ARGs analyzed in this project were being selected for during wastewater treatment. It should be noted that not all ARGs were evaluated in this study. While the two resistant genes selected for this project represent highly prevalent and clinically relevant genes, the possibility cannot be ruled out that other genes might be selected for during wastewater treatment. In addition, operational parameters have been shown to affect ARG concentrations [19,70] thus ARG reductions may differ between facilities operating under different conditions. 


\section{Conclusions}

1. The full-scale tertiary stage WRP reduced concentrations of sul1 by approximately four- $\log _{10}$ from the raw sewage. In addition, the $b a_{S H V / T E M}$ ARG was reduced to below detectable limits in the final effluent (removal of greater than three $\log _{10}$ ).

2. The percentage of ARGs that partitioned with the solids and dissolved phases differed between treatment processes.

3. Positive selection for sul1 or bla $a_{S H V / T E M}$ ARGs, in reference to the total bacterial biomass, was not observed throughout the treatment process.

4. Tertiary media filtration and chlorine disinfection were the most effective treatment processes with respect to ARG reductions.

5. Pilot-scale dual-media filter experiments demonstrated that tertiary filtration enhanced chlorine mediated reduction of an ARG containing plasmid compared to chlorine treatment of secondary effluent.

6. This data demonstrated that tertiary filtration and disinfection can result in additional removal of ARGs compared to non-filtered disinfected secondary effluent.

Supplementary Materials: The following are available online at www.mdpi.com/2073-4441/10/1/37/s1, Figures S1, S2; Tables S1-S12. References [71,72] are cited in the supplementary materials.

Author Contributions: R.A.R. and A.S. conceived and designed the experiments; J.Q.-C., B.H.-L., S.A., C.M. and R.A.R. performed the experiments; R.A.R. analyzed the data and wrote the paper.

Conflicts of Interest: The authors declare no conflict of interest.

\section{References}

1. Mainous, A.G., 3rd; Diaz, V.A.; Matheson, E.M.; Gregorie, S.H.; Hueston, W.J. Trends in hospitalizations with antibiotic-resistant infections: U.S., 1997-2006. Public Health Rep. 2011, 126, 354-360. [CrossRef] [PubMed]

2. Phelps, C.E. Bug/drug resistance: Sometimes less is more. Med. Care 1989, 27, 194-203. [CrossRef] [PubMed]

3. Auerbach, E.A.; Seyfried, E.E.; McMahon, K.D. Tetracycline resistance genes in activated sludge wastewater treatment plants. Water Res. 2007, 41, 1143-1151. [CrossRef] [PubMed]

4. Grabow, W.O.; Prozesky, O.W. Drug resistance of coliform bacteria in hospital and city sewage. Antimicrob. Agents Chemother. 1973, 3, 175-180. [CrossRef] [PubMed]

5. Grabow, W.O.K.; Prozesky, O.W.; Smith, L.S. Drug resistant coliforms call for review of water quality standards. Water Res. 1974, 8, 1-9. [CrossRef]

6. Linton, K.B.; Richmond, M.H.; Bevan, R.; Gillespie, W.A. Antibiotic resistance and R factors in coliform bacilli isolated from hospital and domestic sewage. J. Med. Microbiol. 1974, 7, 91-103. [CrossRef] [PubMed]

7. Niemi, M.; Sibakov, M.; Niemela, S. Antibiotic resistance among different species of fecal coliforms isolated from water samples. Appl. Environ. Microbiol. 1983, 45, 79-83. [PubMed]

8. Reinthaler, F.F.; Posch, J.; Feierl, G.; Wnst, G.; Haas, D.; Ruckenbauer, G.; Mascher, F.; Marth, E. Antibiotic resistance of E. coli in sewage and sludge. Water Res. 2003, 37, 1685-1690. [CrossRef]

9. Chee-Sanford, J.C.; Aminov, R.I.; Krapac, I.J.; Garrigues-Jeanjean, N.; Mackie, R.I. Occurrence and diversity of tetracycline resistance genes in lagoons and groundwater underlying two swine production facilities. Appl. Environ. Microbiol. 2001, 67, 1494-1502. [CrossRef] [PubMed]

10. Koike, S.; Krapac, I.G.; Oliver, H.D.; Yannarell, A.C.; Chee-Sanford, J.C.; Aminov, R.I.; Mackie, R.I. Monitoring and source tracking of tetracycline resistance genes in lagoons and groundwater adjacent to swine production facilities over a 3-year period. Appl. Environ. Microbiol. 2007, 73, 4813-4823. [CrossRef] [PubMed]

11. Sayah, R.S.; Kaneene, J.B.; Johnson, Y.; Miller, R. Patterns of antimicrobial resistance observed in Escherichia coli isolates obtained from domestic- and wild-animal fecal samples, human septage, and surface water. Appl. Environ. Microbiol. 2005, 71, 1394-1404. [CrossRef] [PubMed]

12. Schmitt, H.; Stoob, K.; Hamscher, G.; Smit, E.; Seinen, W. Tetracyclines and tetracycline resistance in agricultural soils: Microcosm and field studies. Microb. Ecol. 2006, 51, 267-276. [CrossRef] [PubMed] 
13. Baquero, F.; Martinez, J.L.; Canton, R. Antibiotics and antibiotic resistance in water environments. Curr. Opin. Biotechnol. 2008, 19, 260-265. [CrossRef] [PubMed]

14. Feary, T.W.; Sturtevant, A.B.J.; Lankford, J. Antibiotic-resistant coliforms in fresh and salt water. Arch. Environ. Health 1972, 25, 215-220. [PubMed]

15. Goni-Urriza, M.; Capdepuy, M.; Arpin, C.; Raymond, N.; Caumette, P.; Quentin, C. Impact of an urban effluent on antibiotic resistance of riverine Enterobacteriaceae and Aeromonas spp. Appl. Environ. Microbiol. 2000, 66, 125-132. [CrossRef] [PubMed]

16. Goñi-Urriza, M.; Pineau, L.; Capdepuy, M.; Roques, C.; Caumette, P.; Quentin, C. Antimicrobial resistance of mesophilic Aeromonas spp. Isolated from two european rivers. J. Antimicrob. Chemother. 2000, 46, 297-301. [CrossRef] [PubMed]

17. Iwane, T.; Urase, T.; Yamamoto, K. Possible impact of treated wastewater discharge on incidence of antibiotic resistant bacteria in river water. Water Sci. Technol. 2001, 43, 91-99. [PubMed]

18. Smith, H.W. Incidence of river water of Escherichia coli containing r factors. Nature 1970, 228, 1286-1288. [CrossRef] [PubMed]

19. Kim, S.; Aga, D.S.; Jensen, J.N.; Weber, A.S. Effect of sequencing batch reactor operation on presence and concentration of tetracycline-resistant organisms. Water Environ. Res. 2007, 79, 2287-2297. [CrossRef] [PubMed]

20. Zhang, Y.; Marrs, C.F.; Simon, C.; Xi, C. Wastewater treatment contributes to selective increase of antibiotic resistance among Acinetobacter spp. Sci. Total Environ. 2009, 407, 3702-3706. [CrossRef] [PubMed]

21. Pruden, A.; Arabi, M.; Storteboom, H.N. Correlation between upstream human activities and riverine antibiotic resistance genes. Environ. Sci. Technol. 2012, 46, 11541-11549. [CrossRef] [PubMed]

22. Martins da Costa, P.; Vaz-Pires, P.; Bernardo, F. Antimicrobial resistance in Enterococcus spp. Isolated in inflow, effluent and sludge from municipal sewage water treatment plants. Water Res. 2006, 40, 1735-1740. [CrossRef] [PubMed]

23. LaPara, T.M.; Burch, T.R.; McNamara, P.J.; Tan, D.T.; Yan, M.; Eichmiller, J.J. Tertiary-treated municipal wastewater is a significant point source of antibiotic resistance genes into Duluth-Superior Harbor. Environ. Sci. Technol. 2011, 45, 9543-9549. [CrossRef] [PubMed]

24. Czekalski, N.; Berthold, T.; Caucci, S.; Egli, A.; Burgmann, H. Increased levels of multiresistant bacteria and resistance genes after wastewater treatment and their dissemination into lake geneva, Switzerland. Front. Microbiol. 2012, 3, 106. [CrossRef] [PubMed]

25. Bockelmann, U.; Dorries, H.H.; Ayuso-Gabella, M.N.; Salgot de Marcay, M.; Tandoi, V.; Levantesi, C.; Masciopinto, C.; Van Houtte, E.; Szewzyk, U.; Wintgens, T.; et al. Quantitative PCR monitoring of antibiotic resistance genes and bacterial pathogens in three European artificial groundwater recharge systems. Appl. Environ. Microbiol. 2009, 75, 154-163. [CrossRef] [PubMed]

26. U.S. Environmental Protection Agency. Guidelines for Water Reuse; U.S. Environmental Protection Agency: Washington, DC, USA, 2004; p. 450.

27. Rose, J.B.; Farrah, S.R.; Harwood, V.J.; Levine, A.; Lukasik, J.; Menendez, P.; Scott, T.M. Reduction of Pathogens, Indicator Bacteria, and Alternative Indicators by Wastewater Treatment and Reclamation Processes; Water Environment Research Foundation: Alexandria, VA, USA, 2004.

28. Asano, T. Wastewater Reclamation and Reuse: Water Quality Management Library; Taylor \& Francis: Milton Park, UK, 1998.

29. Mazel, D.; Davies, J. Antibiotic resistance in microbes. Cell Mol. Life Sci. 1999, 56, 742-754. [CrossRef] [PubMed]

30. Von Wintersdorff, C.J.H.; Penders, J.; van Niekerk, J.M.; Mills, N.D.; Majumder, S.; van Alphen, L.B.; Savelkoul, P.H.M.; Wolffs, P.F.G. Dissemination of antimicrobial resistance in microbial ecosystems through horizontal gene transfer. Front. Microbiol. 2016, 7, 173. [CrossRef] [PubMed]

31. Hu, Y.; Yang, X.; Li, J.; Lv, N.; Liu, F.; Wu, J.; Lin, I.Y.; Wu, N.; Weimer, B.C.; Gao, G.F.; et al. The bacterial mobile resistome transfer network connecting the animal and human microbiomes. Appl. Environ. Microbiol. 2016, 82, 6672-6681. [CrossRef] [PubMed]

32. Allen, H.K.; Donato, J.; Wang, H.H.; Cloud-Hansen, K.A.; Davies, J.; Handelsman, J. Call of the wild: Antibiotic resistance genes in natural environments. Nat. Rev. Microbiol. 2010, 8, 251-259. [CrossRef] [PubMed]

33. Aminov, R.I. The role of antibiotics and antibiotic resistance in nature. Environ. Microbiol. 2009, 11, $2970-2988$. [CrossRef] [PubMed] 
34. Martinez, J.L. The role of natural environments in the evolution of resistance traits in pathogenic bacteria. Proc. Biol. Sci. 2009, 276, 2521-2530. [CrossRef] [PubMed]

35. Martinez, J.L. Environmental pollution by antibiotics and by antibiotic resistance determinants. Environ. Pollut. 2009, 157, 2893-2902. [CrossRef] [PubMed]

36. Bhullar, K.; Waglechner, N.; Pawlowski, A.; Koteva, K.; Banks, E.D.; Johnston, M.D.; Barton, H.A.; Wright, G.D. Antibiotic resistance is prevalent in an isolated cave microbiome. PLoS ONE 2012, 7, e34953. [CrossRef] [PubMed]

37. D'Costa, V.M.; King, C.E.; Kalan, L.; Morar, M.; Sung, W.W.; Schwarz, C.; Froese, D.; Zazula, G.; Calmels, F.; Debruyne, R.; et al. Antibiotic resistance is ancient. Nature 2011, 477, 457-461. [CrossRef] [PubMed]

38. Munck, C.; Albertsen, M.; Telke, A.; Ellabaan, M.; Nielsen, P.H.; Sommer, M.O.A. Limited dissemination of the wastewater treatment plant core resistome. Nat. Commun. 2015, 6. [CrossRef] [PubMed]

39. Negreanu, Y.; Pasternak, Z.; Jurkevitch, E.; Cytryn, E. Impact of treated wastewater irrigation on antibiotic resistance in agricultural soils. Environ. Sci. Technol. 2012, 46, 4800-4808. [CrossRef] [PubMed]

40. Pei, R.; Kim, S.C.; Carlson, K.H.; Pruden, A. Effect of river landscape on the sediment concentrations of antibiotics and corresponding antibiotic resistance genes (ARG). Water Res. 2006, 40, 2427-2435. [CrossRef] [PubMed]

41. Harms, G.; Layton, A.C.; Dionisi, H.M.; Gregory, I.R.; Garrett, V.M.; Hawkins, S.A.; Robinson, K.G.; Sayler, G.S. Real-time PCR quantification of nitrifying bacteria in a municipal wastewater treatment plant. Environ. Sci. Technol. 2003, 37, 343-351. [CrossRef] [PubMed]

42. U.S. Environmental Protection Agency. Method A: Enterococci in Water by Taqman Quantitative Polymerase Chain Reaction (qPCR) Assay; EPA-821-R-10-004; U.S. EPA: Washington, DC, USA, 2010; Volume 2010.

43. Jothikumar, N.; Cromeans, T.L.; Hill, V.R.; Lu, X.; Sobsey, M.D.; Erdman, D.D. Quantitative real-time PCR assays for detection of human adenoviruses and identification of serotypes 40 and 41. Appl. Environ. Microbiol. 2005, 71, 3131-3136. [CrossRef] [PubMed]

44. Malorny, B.; Paccassoni, E.; Fach, P.; Bunge, C.; Martin, A.; Helmuth, R. Diagnostic real-time PCR for detection of Salmonella in food. Appl. Environ. Microbiol. 2004, 70, 7046-7052. [CrossRef] [PubMed]

45. Association, A.P.H. Standard Methods for the Examination of Water and Wastewater; General Books: Vancouver, BC, Canada, 2013.

46. Hicks, L.A.; Bartoces, M.G.; Roberts, R.M.; Suda, K.J.; Hunkler, R.J.; Taylor, T.H., Jr.; Schrag, S.J. US outpatient antibiotic prescribing variation according to geography, patient population, and provider specialty in 2011. Clin. Infect. Dis. 2015, 60, 1308-1316. [CrossRef] [PubMed]

47. Livermore, D.M. Beta-lactamases in laboratory and clinical resistance. Clin. Microbiol. Rev. 1995, 8, 557-584. [PubMed]

48. Yang, Y.; Zhang, T.; Zhang, X.-X.; Liang, D.-W.; Zhang, M.; Gao, D.-W.; Zhu, H.-G.; Huang, Q.-G.; Fang, H.H. Quantification and characterization of $\beta$-lactam resistance genes in 15 sewage treatment plants from East Asia and North America. Appl. Microbiol. Biotechnol. 2012, 95, 1351-1358. [CrossRef] [PubMed]

49. Paterson, D.L.; Bonomo, R.A. Extended-spectrum $\beta$-lactamases: A clinical update. Clin. Microbiol. Rev. 2005, 18, 657-686. [CrossRef] [PubMed]

50. Gillings, M.; Boucher, Y.; Labbate, M.; Holmes, A.; Krishnan, S.; Holley, M.; Stokes, H.W. The evolution of class 1 integrons and the rise of antibiotic resistance. J. Bacteriol. 2008, 190, 5095-5100. [CrossRef] [PubMed]

51. Gillings, M.R.; Gaze, W.H.; Pruden, A.; Smalla, K.; Tiedje, J.M.; Zhu, Y.-G. Using the class 1 integron-integrase gene as a proxy for anthropogenic pollution. ISME J. 2015, 9, 1269-1279. [CrossRef] [PubMed]

52. Olivieri, A.W.; Crook, J.; Anderson, M.A.; Bull, R.J.; Drewes, J.E.; Haas, C.N.; Jakubowski, W.; McCarty, P.L.; Nelson, J.B.R.; Sedlak, D.L.; et al. Expert Panel Final Report: Evaluation of the Feasibility of Developing Uniform Water Recycling Criteria for Direct Potable Reuse; California State Water Resources Control Board: Sacramento, CA, USA, 2016; pp. 165-194.

53. Chen, H.; Zhang, M. Effects of advanced treatment systems on the removal of antibiotic resistance genes in wastewater treatment plants from Hangzhou, China. Environ. Sci. Technol. 2013, 47, 8157-8163. [CrossRef] [PubMed]

54. Lachmayr, K.L.; Kerkhof, L.J.; Dirienzo, A.G.; Cavanaugh, C.M.; Ford, T.E. Quantifying nonspecific TEM beta-lactamase (blaTEM) genes in a wastewater stream. Appl. Environ. Microbiol. 2009, 75, 203-211. [CrossRef] [PubMed] 
55. Munir, M.; Wong, K.; Xagoraraki, I. Release of antibiotic resistant bacteria and genes in the effluent and biosolids of five wastewater utilities in Michigan. Water Res. 2011, 45, 681-693. [CrossRef] [PubMed]

56. Rizzo, L.; Manaia, C.; Merlin, C.; Schwartz, T.; Dagot, C.; Ploy, M.C.; Michael, I.; Fatta-Kassinos, D. Urban wastewater treatment plants as hotspots for antibiotic resistant bacteria and genes spread into the environment: A review. Sci. Total Environ. 2013, 447, 345-360. [CrossRef] [PubMed]

57. Zhang, T.; Zhang, M.; Zhang, X.; Fang, H.H. Tetracycline resistance genes and tetracycline resistant lactose-fermenting Enterobacteriaceae in activated sludge of sewage treatment plants. Environ. Sci. Technol. 2009, 43, 3455-3460. [CrossRef] [PubMed]

58. Zhang, Y.; Zhuang, Y.; Geng, J.; Ren, H.; Zhang, Y.; Ding, L.; Xu, K. Inactivation of antibiotic resistance genes in municipal wastewater effluent by chlorination and sequential UV/chlorination disinfection. Sci. Total Environ. 2015, 512-513, 125-132. [CrossRef] [PubMed]

59. Aminov, R.I. Horizontal gene exchange in environmental microbiota. Front. Microbiol. 2011, 2, 158. [CrossRef] [PubMed]

60. Baur, B.; Hanselmann, K.; Schlimme, W.; Jenni, B. Genetic transformation in freshwater: Escherichia coli is able to develop natural competence. Appl. Environ. Microbiol. 1996, 62, 3673-3678. [PubMed]

61. Guo, M.T.; Yuan, Q.B.; Yang, J. Distinguishing effects of ultraviolet exposure and chlorination on the horizontal transfer of antibiotic resistance genes in municipal wastewater. Environ. Sci. Technol. 2015, 49, 5771-5778. [CrossRef] [PubMed]

62. Bae, S.; Wuertz, S. Discrimination of viable and dead fecal Bacteroidales bacteria by quantitative PCR with propidium monoazide. Appl. Environ. Microbiol. 2009, 75, 2940-2944. [CrossRef] [PubMed]

63. Furukawa, T.; Jikumaru, A.; Ueno, T.; Sei, K. Inactivation effect of antibiotic-resistant gene using chlorine disinfection. Water 2017, 9, 547. [CrossRef]

64. Borjesson, S.; Matussek, A.; Melin, S.; Lofgren, S.; Lindgren, P.E. Methicillin-resistant Staphylococcus aureus (MRSA) in municipal wastewater: An uncharted threat? J. Appl. Microbiol. 2010, 108, 1244-1251. [CrossRef] [PubMed]

65. Borjesson, S.; Melin, S.; Matussek, A.; Lindgren, P.E. A seasonal study of the mecA gene and Staphylococcus aureus including methicillin-resistant $S$. aureus in a municipal wastewater treatment plant. Water Res. 2009, 43, 925-932. [CrossRef] [PubMed]

66. Garcia, S.; Wade, B.; Bauer, C.; Craig, C.; Nakaoka, K.; Lorowitz, W. The effect of wastewater treatment on antibiotic resistance in Escherichia coli and Enterococcus sp. Water Environ. Res. 2007, 79, 2387-2395. [CrossRef] [PubMed]

67. Nagulapally, S.R.; Ahmad, A.; Henry, A.; Marchin, G.L.; Zurek, L.; Bhandari, A. Occurrence of ciprofloxacin-, trimethoprim-sulfamethoxazole-, and vancomycin-resistant bacteria in a municipal wastewater treatment plant. Water Environ. Res. 2009, 81, 82-90. [CrossRef] [PubMed]

68. Rijal, G.K.; Zmuda, J.T.; Gore, R.; Abedin, Z.; Granato, T.; Kollias, L.; Lanyon, R. Antibiotic resistant bacteria in wastewater processed by the metropolitan water reclamation district of greater chicago system. Water Sci. Technol. 2009, 59, 2297-2304. [CrossRef] [PubMed]

69. Luczkiewicz, A.; Fudala-Ksiazek, S.; Jankowska, K.; Quant, B.; Olanczuk-Neyman, K. Diversity of fecal coliforms and their antimicrobial resistance patterns in wastewater treatment model plant. Water Sci. Technol. 2010, 61, 1383-1392. [CrossRef] [PubMed]

70. Kim, S.; Jensen, J.N.; Aga, D.S.; Weber, A.S. Fate of tetracycline resistant bacteria as a function of activated sludge process organic loading and growth rate. Water Sci. Technol. 2007, 55, 291-297. [CrossRef] [PubMed]

71. Bustin, S.A.; Benes, V.; Garson, J.A.; Hellemans, J.; Huggett, J.; Kubista, M.; Mueller, R.; Nolan, T.; Pfaffl, M.W.; Shipley, G.L.; et al. The MIQE guidelines: Minimum information for publication of quantitative real-time pcr experiments. Clin. Chem. 2009, 55, 611-622. [CrossRef] [PubMed]

72. Kralik, P.; Ricchi, M. A basic guide to real time PCR in microbial diagnostics: Definitions, parameters, and everything. Front Microbiol. 2017, 8, 108. [CrossRef] [PubMed]

(C) 2018 by the authors. Licensee MDPI, Basel, Switzerland. This article is an open access article distributed under the terms and conditions of the Creative Commons Attribution (CC BY) license (http://creativecommons.org/licenses/by/4.0/). 